\title{
De andere kant van de ene munt
}

Citation for published version (APA):

Kool, C. J. M. (1996). De andere kant van de ene munt. Maastricht University. https://doi.org/10.26481/spe.19960927ck

Document status and date:

Published: 27/09/1996

DOI:

10.26481/spe.19960927ck

Document Version:

Publisher's PDF, also known as Version of record

\section{Please check the document version of this publication:}

- A submitted manuscript is the version of the article upon submission and before peer-review. There can be important differences between the submitted version and the official published version of record.

People interested in the research are advised to contact the author for the final version of the publication, or visit the DOI to the publisher's website.

- The final author version and the galley proof are versions of the publication after peer review.

- The final published version features the final layout of the paper including the volume, issue and page numbers.

Link to publication

\footnotetext{
General rights rights.

- You may freely distribute the URL identifying the publication in the public portal. please follow below link for the End User Agreement:

www.umlib.nl/taverne-license

Take down policy

If you believe that this document breaches copyright please contact us at:

repository@maastrichtuniversity.nl

providing details and we will investigate your claim.
}

Copyright and moral rights for the publications made accessible in the public portal are retained by the authors and/or other copyright owners and it is a condition of accessing publications that users recognise and abide by the legal requirements associated with these

- Users may download and print one copy of any publication from the public portal for the purpose of private study or research.

- You may not further distribute the material or use it for any profit-making activity or commercial gain

If the publication is distributed under the terms of Article $25 \mathrm{fa}$ of the Dutch Copyright Act, indicated by the "Taverne" license above, 
$P=152275614$

Universiteitsbibliothoek

Ri",ceuniversiteil Limbuig 
Mijnheer de Rector Magnificus, leden van de Universitaire Gemeenschap,

Dames en Heren,

\section{Inleiding}

Traditioneel is een eigen munt één van de belangrijkste symbolen van de macht en onafhankelijkheid van een soevereine natie. De weerstand tegen het opgeven van dit symbool is normaliter dan ook overeenkomstig groot. Zo vermeldt Kindleberger (1993) dat aan het begin van de zeventiende eeuw veertien munten met elkaar concurreerden binnen de jonge Republiek der Zeven Provinciën (één munt voor elk van de provincies en in één provincie zelfs twee, plus zes munten van belangrijke steden). Pogingen van de Staten-Generaal om het aantal munten te beperken of om op zijn minst tot een standaardisatie van de munten te komen, mislukten vanwege het gebrek aan kracht van de centrale overheid. De voorheen onafhankelijke leden van de tamelijk losse federatie die de Republiek op dat moment was, waren duidelijk niet bereid afstand te doen van hun recht op het drukken van 'eigen' geld.

Andersom blijkt telkens weer dat zo gauw de politieke samenhang van een land verdwijnt en een opsplitsing van zo'n land plaatsvindt in meerdere onafhankelijke staten, elk van deze nieuwe staten vrijwel onmiddellijk start met de introductie van een eigen munt. De recente geschiedenis biedt voorbeelden te over, zoals het uiteen vallen van de voormalige Sovjet-Unie, Joegoslavië en Tsjechoslovakije, zie Conway (1995) en Goodhart (1995).

Niettemin zal - als alles volgens plan verloopt - binnen $2 \frac{1}{2}$ jaar, op 1 januari 1999, de derde fase van de Economische en Monetaire Unie (EMU) ingaan in Europa. Op dat moment wordt de verantwoordelijkheid voor het monetaire beleid door de deelnemende landen - waaronder naar alle waarschijnlijkheid ook Nederland - 
overgedragen aan de Europese Centrale Bank (ECB) en worden de wisselkoersen tussen de nationale munten en de nieuwe Europese munt, de euro, definitief gefixeerd. Na een overgangsperiode van uiterlijk $3 \frac{1}{2}$ jaar zal op 1 juli 2002 de gulden ophouden te bestaan als wettig betaalmiddel in Nederland.

Een dergelijke vrijwillige overdracht van monetaire autonomie door soevereine staten aan een supra-nationaal orgaan (de ECB) is uniek in de geschiedenis. De mogelijke consequenties daarvan verdienen dus de nodige discussie. Het resultaat van zo'n discussie in andere landen is dat Noorwegen en Zwitserland bedankt hebben voor de eer deel uit te gaan maken van de Europese Unie, dat het Verenigd Koninkrijk al in 1991 bedongen heeft dat het buiten de monetaire eenwording kan blijven, en dat Denemarken naderhand een soortgelijke mogelijkheid heeft gekregen. ${ }^{1}$

In Nederland ontbreekt een debat over de wenselijkheid of haalbaarheid van de EMU. Uit een in opdracht van De Nederlandsche Bank gehouden enquête in februari van dit jaar, blijkt echter wel dat 71 procent van de ondervraagde particulieren en 81 procent van de bedrijven de euro even aanvaardbaar vindt als de gulden, zie Boeschoten en Stokman (1996). Hiermee is het percentage voorstanders in Nederland beduidend hoger dan het gemiddelde in Europa, dat rond de vijftig procent ligt. Het is overigens niet duidelijk waarop de steun voor de euro in Nederland gebaseerd is. Uit dezelfde enquête blijkt namelijk dat slechts 24 procent van de particulieren en 26 procent van de bedrijven de ontwikkelingen rond de EMU (bijna) altijd volgt en dat 34 respectievelijk 27 procent dat zelden of nooit doet. Bovendien voelt slechts 44 procent van de particulieren en 48 procent van de bedrijven zich over dit onderwerp voldoende geïnfor-

${ }^{1}$ Overigens ook buiten Europa worden met enige regelmaat sceptische geluiden over de wenselijkheid van de EMU geuit, zie bijvoorbeeld Feldstein (1992). 
meerd. Bij degenen die daadwerkelijk het eenwordingsproces volgen is dit maar iets beter: 55 en 57 procent respectievelijk.

$\mathrm{Na}$ deze inleiding laat mijn onderwerp zich raden. Het waarom, hoe, en wanneer van de Economische en Monetaire Unie in Europa verdient gezien het belang van de zaak meer aandacht dan het althans in Nederland - krijgt. Omdat bovendien de voordelen van de EMU meestal aanzienlijk prominenter naar voren worden gebracht dan de ermee gepaard gaande kosten en risico's, wil ik vandaag juist die andere - minder positieve - kant laten zien. Ik hoop u er op zijn minst gedeeltelijk van te overtuigen dat economisch gezien de netto baten van de monetaire eenwording in Europa beperkt zijn, terwijl de risico's aanzienlijk zijn. Vandaar dat ik pleit voor uitstel van monetaire eenwording. Of van uitstel ook afstel moet komen, hangt minder van economische dan van politieke factoren af.

\section{Een korte terugblik}

Voor ik aan het eigenlijke betoog begin, wil ik u eerst de ontwikkelingen op het gebied van de monetaire integratie in Europa sinds 1986 schetsen. 1986 markeert het begin van een succesvolle periode van economische convergentie in Europa. In de Europese Akte wordt de voltooiing van de interne markt per 31 december 1992 tot officiele beleidsdoelstelling verheven. Dit impliceert volledig vrije mobiliteit van goederen en diensten, kapitaal, en arbeid tussen de landen van de Europese Gemeenschap. De hiermee beoogde economische integratie moet resulteren in een efficiënte Europese markt via grotere concurrentie en schaalvoordelen.

Parallel hieraan wordt verder gewerkt aan verdergaande monetai$r e$ integratie om twee redenen Enerzijds vereist dé Europese Akte de afschaffing van de op dat moment nog van kracht zijnde restricties op internationale kapitaalstromen, die een belangrijke rol spelen in het - sinds 1979 bestaande - stelsel van vaste wisselkoersen in Europa. Anderzijds wordt wisselkoersstabiliteit gezien als een nood- 
zakelijke voorwaarde voor de interne markt. In combinatie vraagt dit om grotere coördinatie van het monetair beleid.

Van 1987 tot 1991 blijkt het inderdaad mogelijk om de onderlinge wisselkoersen tussen de - in het vaste wisselkoerssysteem participerende - landen van de Europese Unie binnen een kleine bandbreedte te houden zonder tussentijdse aanpassing van de centrale pariteiten, en kunnen zelfs Spanje, Portugal, en het Verenigd Koninkrijk tot dit stelsel toetreden. Daarnaast nemen de inflatie- en renteverschillen af en worden de bestaande kapitaalrestricties geleidelijk opgeheven. In die sfeer van euro-optimisme lijkt verdere monetaire integratie via volledig vaste wisselkoersen naar één Europese munt nog slechts een kwestie van tijd.

\subsection{Het Verdrag van Maastricht}

In december 1991 bereiken de Europese regeringsleiders in Maastricht dan ook overeenstemming over de te volgen route naar de voltooiing van de Economische en Monetaire Unie. In het Verdrag van Maastricht wordt vastgelegd dat de landen van de Europese Unie zich er toe verplichten hun economieën klaar te maken voor een monetaire unie met één munt. De derde fase daarvan, waarin wisselkoersen volledig vast worden en de verantwoordelijkheid voor het monetaire beleid overgedragen wordt aan een nieuw op te richten Europese Centrale Bank, moet ingaan op 1 januari 1997, als tenminste een meerderheid van de deelnemende landen aan de in het Ver drag gestelde voorwaarden voldoet, of anders op 1 januari 1999 met alleen die landen die er klaar voor zijn. In de statuten van de ECB wordt vastgelegd dat deze in het beleid volledige prioriteit moet geven aan prijsstabiliteit. Ter voorkoming van politieke druk op de ECB om het beleid meer op andere economische doelstellingen zoals bijvoorbeeld werkloosheid te richten, wordt de ECB statutair onafhankelijk gemaakt. 
Volgens de voorwaarden - ook wel convergentiecriteria genoemd in het Verdrag van Maastricht, kan (en moet) een land toetreden tot de derde fase van de EMU als:

- de inflatie niet meer dan 1,5\% hoger ligt dan het gemiddelde van de drie landen met de laagste inflatie,

- de lange-termijn rente niet meer dan $2 \%$ hoger ligt dan de gemiddelde rente in de drie landen met de laagste inflatie,

- de eigen valuta in de twee voorafgaande jaren niet gedevalueerd is,

- het overheidstekort niet groter dan 3\% van het nationaal inkomen is,

- de overheidsschuld niet groter dan $60 \%$ van het nationaal inkomen is, en

- de nationale centrale bank statutair onafhankelijk is gemaakt.

In 1991 lijken deze voorwaarden niet al te restrictief. Immers, voor elk criterium kwalificeren zich dan al ongeveer acht (van de dan twaalf) landen. ${ }^{2}$ Bovendien zijn in het Verdrag nog aanvullende verzachtende omstandigheden opgenomen met betrekking tot de twee criteria op het terrein van de overheidsfinanciën. Vandaar dat bij voorbeeld Gros en Thygesen (1992) concluderen dat "..een horizon van bijna vijf jaar voldoende moet zijn om de huidige EU-landen (misschien met uitzondering van Griekenland) gezamenlijk toe te laten tot de derde fase van de EMU. Als de hiervoor vereiste aanpassing niet binnen vijf jaar kan worden voltooid, is het niet realistisch te denken dat dat in een willekeurig langere periode wel mogelijk zal $z i j n$ " (vertaling auteur).

2 Per 1 januari 1995 zijn Oostenrijk, Finland en Zweden toegetreden tot de Europese. Unie, zodat deze nu uit vijftien landen bestaat. 
Toch is er ook dan al kritiek, zie bijvoorbeeld Fratianni en von Hagen (1992). Die concentreert zich op het feit dat het Verdrag van Maastricht volledig gebaseerd is op de idee dat geleidelijke convergentie van inflatie, rente en overheidsfinanciën een noodzakelijke voorwaarde is voor een monetaire unie en dat tegelijkertijd tijdens dit convergentieproces de onderlinge wisselkoersen steeds minder mogen bewegen ten opzichte van elkaar. Dit zou leiden tot toenemende instabiliteit van het systeem, mogelijk uitmondend in één of meer valutacrises. Laat ik dat toelichten.

\subsection{De valutamarkt als scherprechter}

In het Verdrag van Maastricht is expliciet het tijdstip vastgelegd waarop aan de hand van de convergentiecriteria zal worden besloten of een land toe mag treden tot de EMU: eind 1996 bij een start op 1 januari 1997, eind 1998 bij een start op 1 januari 1999.

Als vlak voor die beslissing, zeg in juni 1996, de kans (te) groot is dat een bepaald land zich niet zal kwalificeren, zullen beleggers massaal de valuta van dat land proberen te verkopen om koersverliezen op hun portefeuille te voorkomen. Omdat beleggers die te laat zijn met verkopen uiteindelijk de kosten moeten dragen, zal elke belegger hierop alert zijn en al eerder actie ondernemen, bijvoorbeeld in mei 1996. Maar als iedereen dat doet, loopt een individuele belegger ook dan al het risico te laat te zijn, dus begint hij zich reeds zorgen te maken in april 1996 et cetera, et cetera.

Het Verdrag van Maastricht zelf geeft dus beleggers de prikkel om continu per land een afweging te maken of de resterende tijd tot het eerste ijkpunt (eind 1996) voldoende is om de binnenlandse aanpassingen door te voeren die nodig zijn om aan de convergentiecriteria te voldoen. Elk stukje nieuwe economische of politieke informatie kan dan de balans doen doorslaan en leiden tot een valuta- 
crisis. ${ }^{3}$ Op zich doen financiële markten daarmee hun werk: ze kijken vooruit en straffen landen die niet snel of vastbesloten genoeg hun beleid aanpassen.

Dit is precies wat er in de praktijk gebeurt. Na de totstandkoming van het Verdrag van Maastricht eind 1991 slaat het euro-optimisme om in europessimisme door een reeks ongunstige gebeurtenissen. De belangrijkste hiervan is waarschijnlijk de recessie die de Europese landen in verschillende mate treft. Deze reduceert de onderlinge bereidheid tot compromisvorming - zie de Grauwe (1994b) - , vermindert de kans dat landen voldoen aan de convergentiecriteria door een verslechtering van de overheidsfinanciën, en veroorzaakt - in de media breed uitgemeten - politieke spanningen tussen Duitsland en Frankrijk over het te voeren monetaire beleid. Zie Eichengreen en Wyplosz (1993) voor een gedetailleerd overzicht.

Als dan uit referenda in Denemarken en Frankrijk ter ratificatie van het Verdrag van Maastricht blijkt dat de publieke opinie sterk verdeeld is over het belang van de EMU, verdwijnt in september 1992 het vertrouwen van valutamarkt-participanten in de snelle totstandkoming van de EMU en komen de zwakker geachte valuta's onder zware druk te staan. Het Britse pond en de Italiaanse lire verlaten het stelsel van vaste wisselkoersen, de Spaanse peseta en de Portugese escudo moeten devalueren. Na hernieuwde valuta-onrust en speculatieve aanvallen op de valuta's van onder andere Frankrijk en België wordt begin augustus 1993 besloten de fluctuatiemarges van het vaste wisselkoers stelsel te verbreden van $2,25 \%$ tot $15 \%$, met uitzondering van de wisselkoers tussen gulden en Duitse mark.

3 Valutacrises kunnen ook autonoom ontstaan door zichzelf vervullende verwachtingen, zie Eichengreen en Wyplosz (1993). 


\subsection{Lessen uit het verleden}

De lering die uit deze gebeurtenissen getrokken kan worden, is dat teruggaan naar bijvoorbeeld de situatie van de periode 1986-1991 onmogelijk is. Een stelsel van vaste wisselkoersen met smalle fluctuatiemarges is onder perfecte kapitaalmobiliteit, asymmetrische schokken en de onvermijdelijk imperfecte coördinatie van monetair beleid uiterst kwetsbaar voor al dan niet economisch gefundeerde speculatieve aanvallen. Voor de toekomst moet de keuze gaan tussen een verdere integratie naar één munt of een wisselkoers-stelsel met aanzienlijk ruimere fluctuatiemarges en flexibiliteit.

Ter illustratie van bovenstaand betoog is in Figuur 1 voor een aantal representatieve landen van de Europese Unie de wisselkoersontwikkeling ten opzichte van de gulden sinds 1979, de start van het Europees Monetair Stelsel van vaste wisselkoersen, weergegeven. ${ }^{4}$ Ter vergelijking is bovendien Zwitserland toegevoegd, dat gedurende de hele periode voor een zwevende wisselkoers en een eigen monetair beleid heeft gekozen. Alle wisselkoersen zijn genormaliseerd op 100 in het eerste kwartaal van 1979. Een stijging is een appreciatie van de gulden. In de grafiek zijn duidelijk drie perioden te onderscheiden. Regelmatige wisselkoersaanpassingen van 1979 tot 1986 , een stabiele periode van 1986 tot 1991 en daarna opnieuw belangrijke wisselkoersbewegingen. De ervaringen van Zwitserland over de hele periode en België in de laatste periode leren dat wisselkoersstabiliteit ook tot de mogelijkheden behoort als wisselkoersen grotere bewegingsvrijheid hebben.

${ }^{4}$ Alle voor figuren en tabellen gebruikte data zijn afkomstig uit Datastream. 
Figuur 1 Nominale wisselkoersen in Europa (t.o.v. de gulden; $1979=100$ )

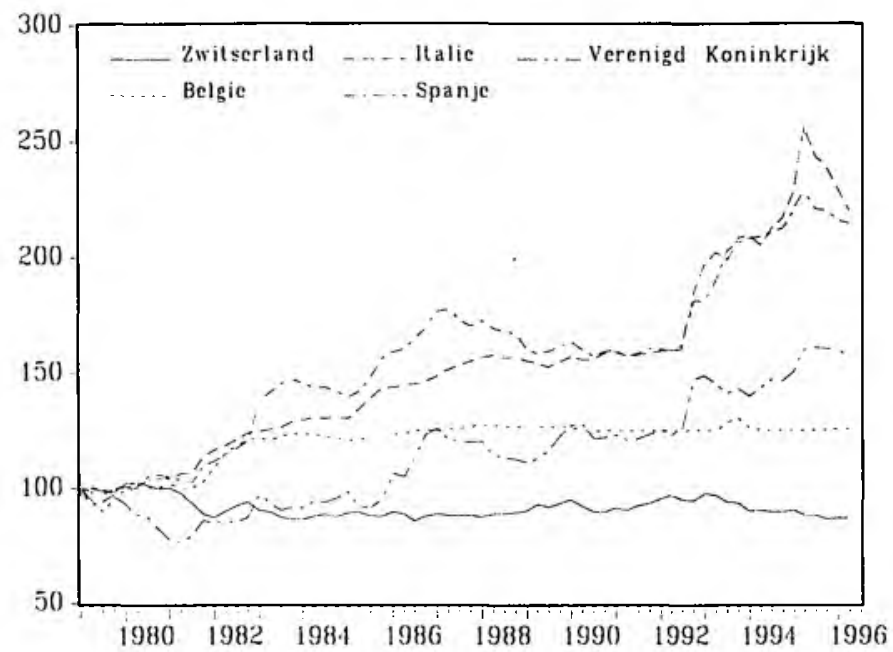

In tabel 1 wordt voor alle vijftien landen van de Europese Unie zowel het bereikte minimum- als maximumniveau van de wisselkoers over de hele periode als de variabiliteit van de wisselkoers (gemeten als de standaarddeviatie van kwartaal-op-kwartaal veranderingen t.o.v. de gulden) in procenten op jaarbasis in vier deelperioden weergegeven. Ter vergelijking worden dezelfde gegevens voor Japan, Zwitserland en de Verenigde Staten gepresenteerd die een zwevende wisselkoers met Nederland gehad hebben over de hẻle periode.

Uit de tabel blijkt dat voor sommige landen grote trendmatige niveau-veranderingen hebben plaatsgevonden; zo is bijvoorbeeld de genormaliseerde koers van de Griekse drachme van 100 naar ruim 800 gegaan, een depreciatie van 700 procent. 
Tabel 1 Karakteristieken van nominale wisselkoersen (t.o.v. de gulden; $1979=100$ )

\begin{tabular}{|c|c|c|c|c|c|c|}
\hline Land & $\min$ & $\max$ & standa & ddevia & e (\% per & aar) \\
\hline Lid EU in 1979 & $79: 1-5$ & & $74: 1-$ & $79: 3-$ & $85: 1-$ & $90: 3-$ \\
\hline België/Luxemburg & 997 & 1309 & 30 & 80 & 21 & 4.1 \\
\hline Denemarken & 100,0 & 138,5 & 4,8 & 6,5 & 3,4 & 4.2 \\
\hline Frankrijk & 99,5 & 148,4 & 13,1 & 8,2 & 4,1 & 4,1 \\
\hline Duitsland & 95,5 & 100,0 & 4,6 & 3,5 & 1,1 & 0,5 \\
\hline Ierland & 97,3 & 159,0 & 17,9 & 4,3 & 6,7 & 7,4 \\
\hline Italië & 97,5 & 256,8 & 17,1 & 6,3 & 5,6 & 19,0 \\
\hline Verenigd Koninkrijk & 76,6 & 161,5 & 18,7 & 18,5 & 17,9 & 16,8 \\
\hline Lid EU na 1979 & & & & & & \\
\hline Spanje & 92,7 & 228,9 & 21,2 & 14,1 & 9,8 & 12,6 \\
\hline Portugal & 100,0 & 401,8 & 15,8 & 18,8 & 8,7 & 8,6 \\
\hline Griekenland & 98,7 & 809,4 & 17,7 & 14,5 & 16,7 & 7,1 \\
\hline Lid EU vanaf 1995 & & & & & & \\
\hline Oostenrijk & 91,7 & 100,0 & 3,8 & 4,2 & 1,1 & 0,9 \\
\hline Zweden & 87,9 & 215,9 & 10,0 & 21,0 & 8,3 & 19,2 \\
\hline Finland & 81,9 & 151,7 & 20,1 & 12,4 & 8,1 & 18,5 \\
\hline Buiten EU & & & & & & \\
\hline Zwitserland & 86,1 & 102,6 & 15,4 & 9,5 & 7,0 & 7,4 \\
\hline Japan & 54,4 & 125,7 & 20,1 & 21,4 & 17,3 & 20,3 \\
\hline Verenigde Staten & 54,9 & 128,4 & 17,3 & 19,6 & 22,1 & 22,0 \\
\hline
\end{tabular}


Voor andere landen als Duitsland, Oostenrijk, en Zwitserland is de waardeverandering ten opzichte van de gulden veel beperkter geweest. Daarnaast valt op dat de korte-termijn wisselkoersvariabiliteit aanmerkelijk verminderd is vanaf 1985, met name voor de oorspronkelijke leden van het Europees Monetair Stelsel. De variabiliteit van de Italiaanse lire is na 1990 terug op het niveau van de zeventiger jaren, voor de meeste andere landen stabiliseert de variabiliteit zich.

Figuur 2 Inflatieconvergentie in Europa

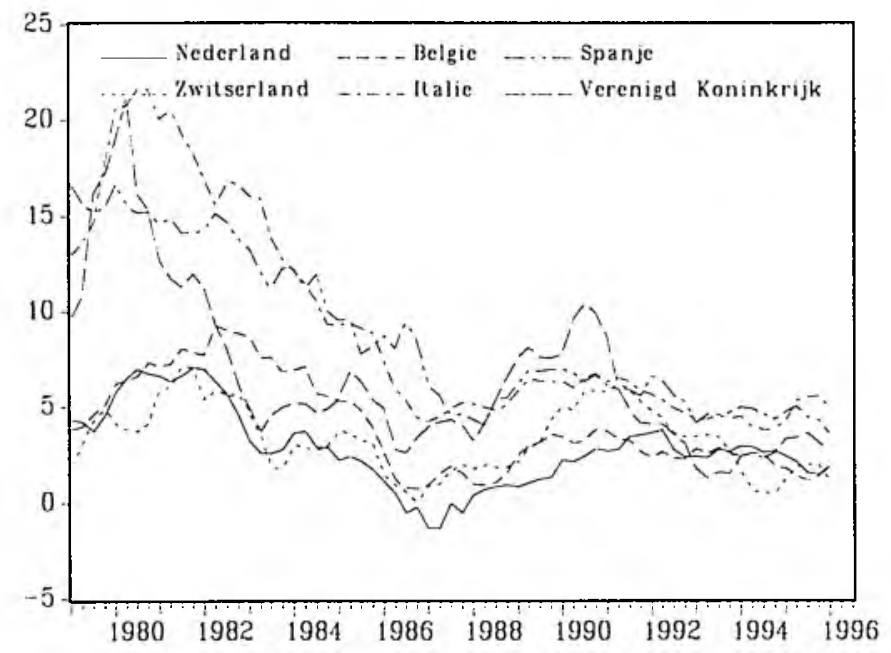

In figuren 2 en 3 is voor dezelfde groep landen plus Nederland het verloop van respectievelijk inflatie en lange rente gegeven. De convergentie in de jaren tachtig is duidelijk. Overigens blijkt wel dat de toegenomen wisselkoersvolatiliteit sinds 1992 niet heeft geleid tot 
verwachten dat zijn internationale handel $68 \%$ hoger zal komen te liggen dan op basis van andere factoren kan worden verklaard. Ten opzichte hiervan is het geschatte effect van wisselkoersvariabiliteit verwaarloosbaar klein. Volgens Frankel en Wei heeft de reductie in wisselkoersvariabiliteit in Europa tussen 1980 en 1990 minder dan $1 \%$ extra intra-Europese handel opgeleverd. Dus de totstandkoming van de interne markt weegt in dit opzicht aanzienlijk zwaarder dan de gerealiseerde wisselkoersstabiliteit.

Natuurlijk zijn er nog andere voordelen verbonden aan een monetaire unie, zoals de reductie in transactiekosten bij het wisselen van de ene munt in de andere, en een betere vergelijkbaarheid van goederenprijzen in verschillende landen, wat leidt tot meer concurrentie. De consensus lijkt echter te zijn dat de directe kwantitatieve voordelen hiervan beperkt zijn, waar bovendien eenmalige kosten voor de overgang naar de EMU tegenover staan. Voor zover een hogere economische groei in het verschiet ligt, lijkt ook die meer af te hangen van de interne markt dan van de monetaire unie. Voor een meer gedetailleerde afweging van kosten en baten verwijs ik naar Bean (1992), Eichengreen (1993), CPB (1996), de Grauwe (1994a), en Taylor (1995).

\subsection{Monetaire unie als voorwaarde voor economische unie}

Bij het ontbreken van belangrijke directe voordelen van het doen verdwijnen van wisselkoersfluctuaties, wordt de cruciale vraag of de monetaire unie noodzakelijk is voor de interne markt, die immers wel grote voordelen biedt. Het antwoord hangt vooral af van de visie die men heeft op de rol van reële wisselkoersaanpassingen.

Diegenen die de reële wisselkoers vooral zien als een instrument van nationale overheden om de eigen concurrentiepositie te verbeteren ten koste van andere landen via een reële depreciatie, vrezen de spanningen die een dergelijke poging tot concurrentievervalsing zal 
oproepen in de interne markt en willen die mogelijkheid bij voorbaat uitsluiten door een monetaire unie te vormen. ${ }^{5}$

Naar mijn mening is de kans dat landen van de Europese Unie bewust en actief gebruik zullen gaan maken van de mogelijkheid om via depreciaties hun concurrentiepositie te verbeteren tamelijk klein. Belangrijkste argument daarbij is welbegrepen eigenbelang. Elk land is zich bewust van de voordelen van de interne markt en zal deze onder normale omstandigheden niet in gevaar willen brengen. Het feit dat geen enkel land na de valutacrises van 1992-1993 geprobeerd heeft de toegestane fluctuatiemarges van vijftien procent ten eigen bate te exploiteren, ondersteunt mijn argument. Het blijft echter zo dat alleen een volledige monetaire unie zulke competitieve devaluaties echt onmogelijk maakt.

\subsection{Het verlies van de wisselkoers als aanpasser}

Diegenen die de reële wisselkoers vooral zien als een relatieve prijs tussen de goederenpakketten van twee landen, benadrukken dat de reële wisselkoers zich zoals elke andere prijs moet kunnen aanpassen bij veranderingen in vraag en aanbod om de markt weer in evenwicht te brengen. Valt dit evenwichtsbrengend mechanisme weg, dan verplaatst de spanning zich naar prijs- of hoeveelheidsaanpassingen op andere markten, zoals de binnenlandse goederen- en arbeidsmarkt. Aangezien de aanpassingssnelheid op deze laatste markten over het algemeen laag is door onder andere langdurige looncontracten en arbeidswetgeving, biedt in zo'n geval de valutamarkt een veel efficienter aanpassingsmechanisme, dat overigens uiteindelijk ook in de reële lonen moet doorwerken.

${ }^{5}$ Saillant detail hierbij is dat in de zestiger jaren precies het omgekeerde argument gebruikt werd, namelijk dat vaste wisselkoersen de oorzaak zijn van protectionisme en dat voor vrijhandel een zwevend wisselkoerssysteem nodig is, zie Eichengreen (1996). 
Figuur 4 geeft - conform figuur 1 - enig inzicht in de ontwikkeling van reële wisselkoersen in Europa, waarbij gebruik is gemaakt van groothandelsprijzen en 1979 opnieuw op 100 is gezet. Uit de figuur blijkt dat het niveau van de reële wisselkoers aanzienlijk minder trendmatige bewegingen vertoont dan de nominale koers in figuur 1. Voor de meeste landen blijft de wisselkoers rond de 100 fluctueren. Niettemin doen zich regelmatig systematische afwijkingen van 100 voor van tientallen procenten die gedurende meerdere jaren gehandhaafd blijven en die dus tot semi-permanente veranderingen in de onderlinge concurrentiepositie leiden. Opvallend genoeg heeft $Z$ witserland, ondanks de zwevende nominale wisselkoers, de meest stabiele reële koers.

Figuur 4 Reële wisselkoersen in Europa (t.o.v. de gulden, $1979=100$ )

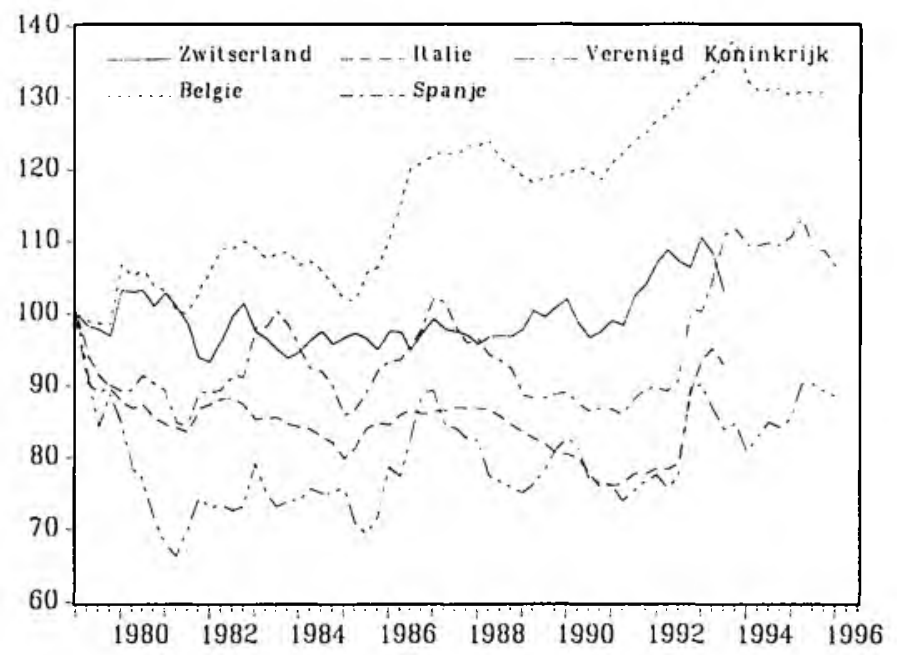


Tabel 2 Karakteristieken van reële wisselkoersen (t.o.v. de gulden; $1979=100$ )

\begin{tabular}{|c|c|c|c|c|c|c|}
\hline \multirow{4}{*}{\begin{tabular}{|l|} 
Land \\
Lid EU in 1979 \\
Reloï//L
\end{tabular}} & $\min$ & $\max$ & \multicolumn{4}{|c|}{ standaarddeviatie (\% per jaar) } \\
\hline & \multirow{2}{*}{\multicolumn{2}{|c|}{$79: 1-95: 3$}} & $74: 1-$ & $79: 3-$ & $85: 1-$ & $90: 3-$ \\
\hline & & & & & & \\
\hline & 98,4 & 138,0 & 6,7 & 10,0 & 7,5 & 5,8 \\
\hline Denemarken & 89,1 & 105,1 & 7,3 & 6,3 & 5,7 & 6,6 \\
\hline Frankrijk (80:1-) & 97,7 & 124,5 & - & 10,4 & 5,5 & 6,5 \\
\hline Duitsland & 94,5 & 100,0 & 6,0 & 4,4 & 2,3 & 2,4 \\
\hline Ierland & 87,7 & 112,5 & 16,5 & 5,6 & 6,9 & 6,3 \\
\hline Italië ( - 93:3) & 76,0 & 100,0 & 15,9 & 5,9 & 5,2 & 15,5 \\
\hline Verenigd Koninkrijk & 66,3 & 100,2 & 18,5 & 18,2 & 16,7 & 18,0 \\
\hline \multicolumn{7}{|l|}{ Lid EU na 1979} \\
\hline Spanje & 84,4 & 113,4 & 18,4 & 11,2 & 9,3 & 12,3 \\
\hline Portugal ( - 86:4) & 75,9 & 109,0 & 14,6 & 18,6 & - & - \\
\hline Griekenland & 80,9 & 105,3 & 19,8 & 9,5 & 10,3 & 6,4 \\
\hline \multicolumn{7}{|l|}{ Lid EU vanaf 1995} \\
\hline Oostenrijk & 92,0 & 104,7 & 5,5 & 8,5 & 6,3 & 6,4 \\
\hline Zweden & 78,1 & 116,5 & 11,5 & 16,8 & 9,2 & 14,9 \\
\hline Finland & 70,4 & 112,8 & 20,9 & 12,0 & 10,1 & 19,1 \\
\hline \multicolumn{7}{|l|}{ Buiten EU } \\
\hline Zwitserland ( $-93: 3)$ & 93,2 & 110,5 & 15,5 & 10,3 & 6,5 & 10,7 \\
\hline Japan & 73,9 & 110,9 & 20,6 & 18,0 & 15,7 & 17,6 \\
\hline Verenigde Staten & 53,4 & 111,0 & 18,7 & 18,1 & 21,6 & 22,1 \\
\hline
\end{tabular}


Tabel 2 - die qua opzet identiek is aan tabel 1 - geeft een breder beeld van reële wisselkoersfluctuaties binnen Europa. Een beperkte groep landen heeft een vrij stabiele reële wisselkoers met Nederland, zoals Duitsland, Oostenrijk, en in iets mindere mate Denemarken en Zwitserland. Over de periode 1979-1996 bewegen deze wisselkoersen zich in een bandbreedte van 10 à 15 procent. Ik wijs er op dat noch Oostenrijk noch Zwitserland traditioneel tot het Europees Monetair Stelsel horen. Voor landen als België, Frankrijk en Ierland die toch normaliter tot de harde kern van de Europese Unie gerekend worden, is de gebruikte bandbreedte al groter, om maar niet te spreken van de overige landen. Opvallend is ook dat de landen die een grote nominale wisselkoersstabiliteit met Nederland gekend hebben sinds 1985 - België, Denemarken, en Oostenrijk bijvoorbeeld - een aanmerkelijk hogere reële dan nominale wisselkoersvariabiliteit laten zien. Dit geeft aan dat deze reële wisselkoersfluctuaties grotendeels aanpassingen via inflatieverschillen reflecteren. Als zodanig geven ze ook de orde van grootte aan van de benodigde interne aanpassing in een toekomstige monetaire unie.

Als alternatieve maatstaf voor het belang van reële onevenwichtigheden, wordt in tabel 3 de mate van integratie van de Nederlandse economie in Europa weergegeven via de correlatie van aandelenrendementen, renteveranderingen en economische groei tussen Nederland en elk van de andere landen. De achterliggende gedachte is dat hoe meer economieën op elkaar lijken qua structuur en hoe sterker ze geïntegreerd zijn, des te minder kans er is op reële onevenwichtigheden, zodat de wisselkoers niet nodig is als extra instrument bij het evenwichtsherstel. Een dergelijke groep landen noemt men een 'optimaal valutagebied'. 
Tabel 3 De integratie van Nederland in Europa (correlatie-coëfficiënt)

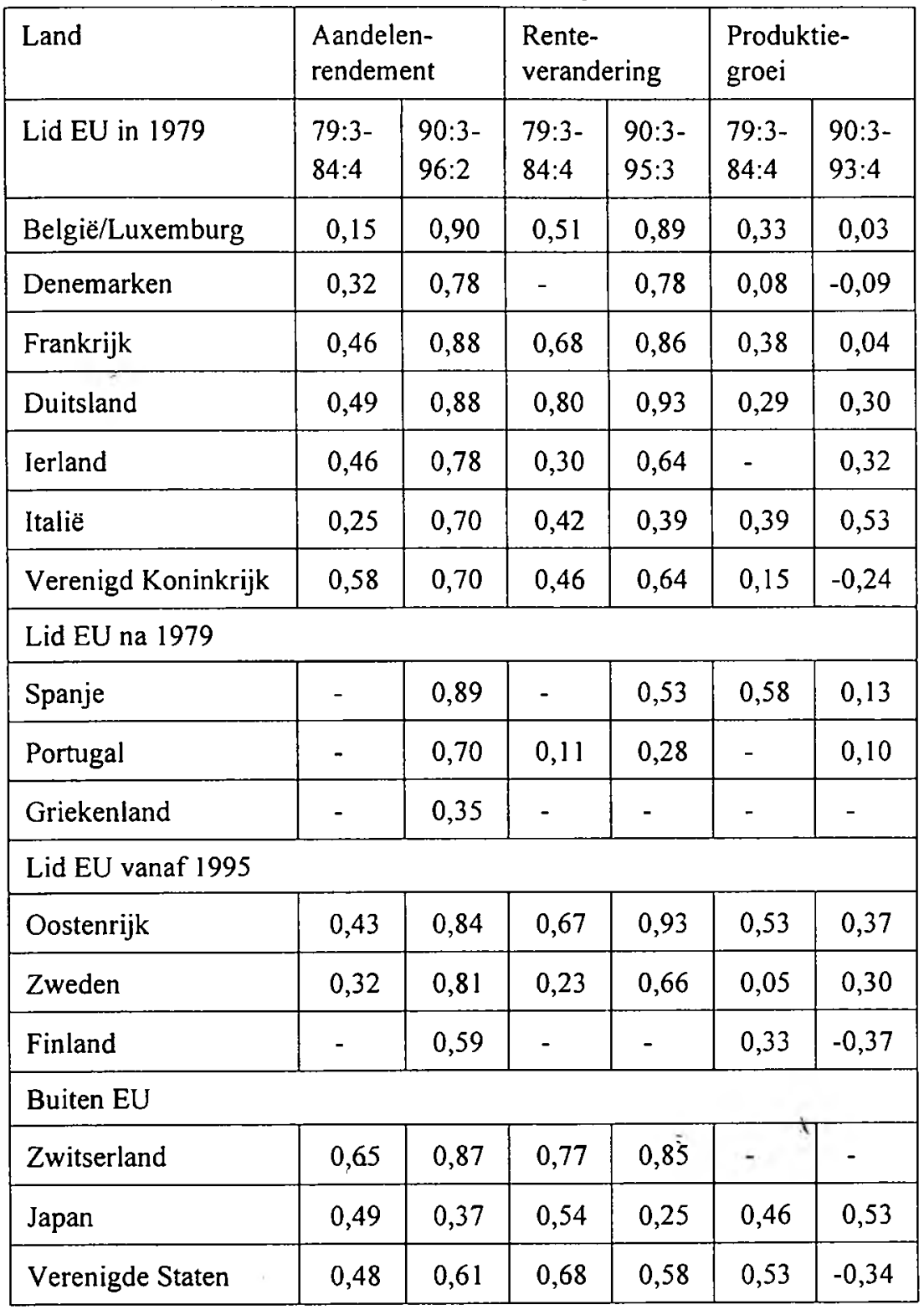


Uit de tabel blijkt dat financiële markten de laatste jaren steeds verder geïntegreerd zijn geraakt. Dit geldt met name voor de oude kern van de Europese Unie, Duitsland en Frankrijk met de er omheen liggende kleine landen België, Luxemburg, Denemarken, en Nederland. Ook Oostenrijk en Zwitserland horen daar overigens bij. Of deze groep landen daarmee een optimaal valutagebied is, blijft twijfelachtig, vooral als gekeken wordt naar de onderlinge samenhang van de productiegroei. Hier zijn de correlaties vrijwel nul. Dit strookt met de geobserveerde reële wisselkoersfluctuaties in tabel 2. Het Europa van de vijftien is echter zeker geen optimaal valutagebied, zie ook Brakman en Garretsen (1996). Bovendien is onzeker of het ontstaan van de EMU de kans op reële onevenwichtigheden zal vergroten of verkleinen. Voor beide mogelijkheden zijn goede argumenten aan te voeren.

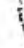 \\ 3.4 Monetaire unie en politieke unie}

In de inleiding heb ik reeds geconstateerd dat er een vrijwel perfecte correspondentie bestaat tussen naties en munteenheden. Het streven naar één munt wordt door sommigen dan ook expliciet gekoppeld aan het streven naar een Europese federale staat. Zo stelt de Delors (1996), de vorige president van de Europese Commissie, dat de wens om tot verdergaande politieke integratie te komen altijd de belangrijkste reden voor economische en monetaire integratie in Europa is geweest. Alleen vanwege de diepe meningsverschillen over de vorm en inhoud van zo'n politieke samenwerking, is de indirecte economische weg gevolgd. Het belang van de EMU is volgens Delors dat "de ervaring van gedeelde soevereiniteit op monetair gebied tot een belangrijke stap voorwaarts in de richting van echte politieke integratie zal leiden" (vertaling auteur).

De problemen rond een politieke unie blijken ook uit het Verdrag van Maastricht dat naast de bepalingen over EMU twee politieke pijlers met betrekking tot de interne en externe veiligheid bevat. De 
Franse wens tot een meer symmetrisch 'Europees' monetair beleid te komen via een monetaire unie is gecombineerd met de Duitse wens naar politieke inbedding. De huidige intergouvernementele conferentie (igc) die half 1997 besloten wordt, heeft de taak betere instituties te ontwikkelen om de politieke besluitvorming te verbeteren. Gezien de meningsverschillen lijkt vooruitgang niet erg waarschijnlijk. Terwijl Duitsland gecharmeerd is van politieke unie (federale structuur), is Frankrijk de voorvechter van intergouvernementele besluitvorming. Bovendien wordt in de discussie één van de belangrijkste aspecten van politieke unie, namelijk de bevoegdheid over het fiscale beleid, buiten beschouwing gelaten.

Mijns inziens is het geen goede zaak om politieke unie af te willen dwingen via monetaire unie. Dat verhoogt de risico's van de EMU. Als er goede redenen zijn om tot politieke unie te komen, is het verstandiger hiervoor rechtstreeks de steun van de bevolking te vragen. Hetzelfde geldt als politieke unie vereist is voor een monetaire unie.

\subsection{Evaluatie}

De economische argumenten vóór monetaire unie lijken niet al te sterk. De kosten van wisselkoersfluctuaties in termen van internationale handel en groei zijn nauwelijks aan te tonen, wellicht omdat bedrijven hierop anticiperen via het afdekken van valutarisico op financiële markten op korte termijn en via de internationale allocatie van investeringen op langere termijn. ${ }^{6}$

Manipulatie van wisselkoersen door individuele landen lijkt onwaarschijnlijk, juist omdat het de interne markt in geқaar kan brengen. Het is echter niet.volledig uit te sluiten. Aan de andere kant

${ }^{6}$ Zo investeert Nederland meer in de Verenigde Staten dan in enig ander land, wellicht mede vanwege de variabele gulden/dollar koers. 
is Europa zeker geen optimaal valutagebied zodat het verlies van de reële wisselkoers als aanpasser kosten met zich kan meebrengen. Dit geldt ook hoewel in mindere mate voor de harde kern van Europa. Pogingen om via een monetaire unie een politieke unie dichter bij te brengen zijn vooral door de grote meningsverschillen uitermate riskant. Als een politieke unie noodzakelijk is voor een monetaire unie, hoort nu eerst de discussie gevoerd te worden over de gewenste vorm en inhoud van zo'n politieke unie, voordat EMU'een feit is.

\section{EMU: hoe?}

Ondanks de twijfels over het nut van de EMU, wordt er op dit moment van uit gegaan dat in maart of april 1998 aan de hand van de convergentie-criteria beoordeeld zal worden welke landen per 1 januari 1999 over mogen gaan naar de derde fase van de EMU. Het is nu al zeker dat in dit scenario een tweedeling ontstaat van een beperkte groep landen die zich direct kwalificeren en een groep achterblijvers, die geacht worden hun beleid te blijven afstemmen op het behalen van de criteria op een later tijdstip, waarop dan toetreding mogelijk is. In 1995 is Luxemburg het enige land dat strikt aan alle criteria voldoet. Ik ga er gemakshalve maar van uit dat zowel Duitsland als Frankrijk er in slagen zich te kwalificeren. Is dat niet het geval, dan lijkt uitstel in ieder geval onvermijdelijk.

Hoe dan ook, in eerste instantie zal slechts een kleine groep meedoen en moet voor de overige landen een overgangsregeling getroffen worden. Verschillende nu al te voorspellen problemen maken de risico's van zo'n EMU naar verwachting vooral gedurende de eerste jaren groot.

\subsection{EMU met criteria}

Allereerst zullen de zich op basis-van de convergentie-criteria kwalificerende landen samen hoogstwaarschijnlijk geen optimaal valuta- 
gebied vormen. Ierland is bijvoorbeeld volgens tabel 3 zelfs op financieel gebied nog niet volledig geïntegreerd met Nederland. Goederen- en arbeidsmarktintegratie is tussen landen als Duitsland, Frankrijk, België en Nederland die onderling wel een hoge graad van financiële integratie hebben, nog verre van perfect.

De kans op asymmetrische schokken is dus zelfs binnen de groep landen die waarschijnlijk door gaan naar de derde fase van de EMU niet onaanzienlijk. Mocht zo'n schok, bijvoorbeeld een recessie die niet precies synchroon verloopt, zich voordoen, dan is het monetaire beleid, dat wil zeggen de wisselkoers, niet meer beschikbaar als (automatische) aanpasser.

Maar ook financieel overheidsbeleid zal de eerste jaren niet ter beschikking staan om dergelijke schokken te absorberen. Enerzijds zullen naar verwachting de in het Verdrag van Maastricht geformuleerde normen voor budgettaire discipline binnen de EMU gehandhaafd of zelfs aangescherpt worden. ${ }^{7}$ Anderzijds valt te verwachten dat de gekwalificeerde landen lang niet allemaal de sanering van hun eigen overheidsfinanciën voltooid zullen hebben. Een aantal zit zeker nog met een (veel) te hoge schuldquote en met een overheidstekort rond het toegestane maximum van 3 procent.

Bij afwezigheid van de normale automatische stabilisatoren zal elk land op andere wijze eventuele negatieve schokken moeten opvangen. De bereidheid om hiervoor offers te brengen zal onder de bevolking echter niet groot zijn. Immers, in veel landen is de sanering van de overheidsfinanciën de afgelopen jaren ondanks sociale onrust in gang gezet en verdedigd door te wijzen op het belang van

${ }^{7}$ Zo heeft de Duitse minister Waigel een stabiliteitspact voorgesteld tussen de landen die toetreden tot de EMU, waarin het gemiddeld toegestane overheidstekort I procent van het nationaal inkomen is. 
de EMU. ${ }^{8}$ Deze onterechte koppeling - zie Wellink (1996) - heeft ontegenzeggelijk bijgedragen aan het succes van de sanering, maar kan nu onbedoeld het succes van de EMU gaan tegenwerken. In het hier geschetste scenario kan de politiek-economische spanning tussen de deelnemende landen snel oplopen en zal bovendien de druk op de ECB om een accommoderend beleid te voeren om de EMU te redden snel toenemen.

Een tweede probleem betreft het ontwerp van een levensvatbaar wisselkoersregime tussen de landen van de eerste en tweede categorie, de ins en outs, zie Vinãls (1996) en Wellink en Knot (1996). Nauwe fluctuatiemarges (met vrije kapitaalmobiliteit) roepen het schrikbeeld op van nieuwe speculatieve aanvallen. Wijdere fluctuatiemarges zijn dus onvermijdelijk, maar leiden zeer waarschijnlijk tot grotere wisselkoersfluctuaties. In de praktijk zal het voor de 'outs' moeilijk zijn hun nominale wisselkoers stabiel te houden, ook zonder bewuste manipulatie van wisselkoersen om een concurrentievoordeel te krijgen. Er is een behoorlijke kans op reële wisselkoersveranderingen vanwege asynchrone recessies, productiviteitsverschillen tussen landen, en zelfs door verschillen in budgettair beleid. ${ }^{9}$ Daarbij komt dat het vaak uiterst moeilijk is om de oorzaak van nominale wisselkoersfluctuaties te bepalen.

${ }^{8}$ Een structurele aanpassing van de overheidsfinanciën is overigens in veel landen noodzakelijk. Alesine en Perotti (1995b) demonstreren dat zo'n sanering duurzamer en succesvoller is als deze plaatsvindt in een hoogconjunctuur en door vermindering van de uitgaven. Het Verdrag van Maastricht gaat voorbij aan zulke overwegingen.

${ }^{9}$ Volgens de theorie zal een land dat een relatief krap financieel overheidsbeleid voert, een reële depreciatie ondervinden. Hierdoor worden de binnenlandse gevolgen van dit beleid enigszins gedempt. Aangezien landen die niet direct toetreden tot de EMU in het algemeen juist de landen zijn die hun overheidsfinanciën nog verder moeten saneren, is dit laatste punt zeker van toepassing. 
Overigens illustreert dit de inconsistentie van het Verdrag van Maastricht: de EMU wordt met name noodzakelijk geacht vanwege de bedreiging van wisselkoersfluctuaties voor de interne markt, terwijl anderzijds probleemloos geaccepteerd wordt dat een grote groep landen voor onbepaalde tijd een eigen munt houdt, met bijbehorende - en relatief grote - wisselkoersfluctuaties.

Ten derde krijgen de 'outs' het door de tweedeling moeilijker om aan de criteria te voldoen: hun rente blijft een forse risicopremie bevatten, zodat renteconvergentie onwaarschijnlijker wordt, en daardoor blijft ook de budgettaire situatie relatief moeilijk. Immers dit zijn de landen met vaak een hoge staatsschuld en dus zwaar drukkende rentelasten op het overheidsbudget, zie de Grauwe (1996). Dit kan het convergentieproces aanzienlijk verlengen of zelfs onmogelijk maken, met alle risico's van dien voor de interne markt.

Een vierde probleem betreft de te grote beleidsrigiditeit en onafhankelijkheid van de ECB. Hoewel het uitbannen van zowel monetaire financiering van de overheidsuitgaven als korte-termijn manipulatie van het monetair beleid door de overheid een goede zaak is, schiet de slinger te ver door. Het is niet waarschijnlijk dat het nastreven van prijsstabiliteit met verwaarlozing van alle andere aspecten een optimale strategie is, zie bijvoorbeeld Keuzenkamp (1996) en Orphanides en Wilcox (1996). Daarbij wordt de ECB zodanig onafhankelijk gemaakt dat er een democratisch gat ontstaat: de ECB kan niet beleidsmatig gecorrigeerd worden tenzij via een wijziging van het Verdrag van Maastricht die door alle deelnemende landen moet worden goedgekeurd. Hiermee is het monetair beleid volledig 'technocratisch' geworden. ${ }^{10}$

${ }^{10}$ De nationale centrale banken dienen op soortgelijke wijze onafhankelijk gemaakt te worden. In Nederland moet hierdoor helaas het (overigens nooit gebruikte) aanwijzingsrecht van de Minister van Financiën, die daarover weer verantwoording schuldig is aan de volksvertegenwoordiging, verdwijnen. 
Het is onwaarschijnlijk, zie Eichengreen (1996), dat het gebrek aan democratische legitimiteit gecompenseerd wordt door het Verdrag van Maastricht alleen. Enerzijds omdat de ECB in haar beleid keuzes kan maken die afwijken van (andermans perceptie van) het doel van prijsstabiliteit, anderzijds omdat niet alle belangengroepen een gelijke mate van voorkeur voor prijsstabiliteit hebben.

Eén mogelijkheid ter correctie is de vorming van een politieke unie, waarbij de ECB verantwoording schuldig is aan het Europees parlement. In dat geval moet echter eerst de discussie over vorm en inhoud van zo'n politieke unie gevoerd worden. Een andere mogelijkheid is de groei van de reputatie van de ECB op basis van het gevoerde beleid. Dit laatste gaat voorbij aan de korte- en middellange termijn problematiek. De eerste jaren na de start van de EMU zijn uitermate risicovol. Een ECB zonder reputatie en zonder democratische legitimiteit kan dan snel onder druk komen te staan.

\subsection{EMU zonder criteria}

De economische onderbouwing van de convergentie-criteria is omstreden, zie bijvoorbeeld ook Buiter et. al. (1993). Daarom pleit de Grauwe (1994b, 1996) voor een alternatieve benadering waarbij alle landen die dat willen onmiddellijk tot de derde fase toegelaten worden. Het probleem van wisselkoersonzekerheid en speculatieve aanvallen verdwijnt dan. Renteverschillen zullen afnemen maar niet verdwijnen omdat verschillen in kredietwaardigheid leiden tot risicopremies.

Tegenstanders van dit voorstel wijzen erop dat de kans op macroeconomische instabiliteit en politieke spanningen binnen de Europese Unie dan sterk zal toenemen vanwege inflatieverschillen bij de start van EMU, de (relatief) slechte budgettaire situatie in de landen die eigenlijk niet aan de criteria voldoen en de aanzienlijke verschillen in economische ontwikkeling en structuur in een grote EMU. 
Hierop valt wel wat af te dingen. In 1995 voldeden al elf van de vijftien landen aan de inflatienorm uit het Verdrag van Maastricht, drie landen - Portugal, Spanje, en Italië - zaten er dicht bij, en alleen Griekenland week met een inflatie van $9,3 \%$ belangrijk af. Door de structurele breuk in de dynamiek van inflatie die met de invoering van de EMU gepaard gaat, zullen prijzen en lonen zich bovendien naar verwachting snel aanpassen. De verstorende rol van bestaande inflatieverschillen valt dus wel mee.

Ook valt te betwijfelen of convergentie van overheidstekorten en -schuld noodzakelijk is voor een stabiele monetaire unie. Voor zover een land een te hoge schuld of een te hoog tekort heeft, zal de markt een risicopremie en een hogere rente eisen. Zolang duidelijk is dat de andere landen niet opdraaien voor de schuld van het betrokken land in problemen, lijkt het niet waarschijnlijk dat de Europese rente als geheel omhoog zal gaan, temeer daar de markt voor obligaties dermate geïnternationaliseerd is, dat mondiale rentebewegingen grotendeels de Europese rente bepalen, zie bijvoorbeeld Koedijk, Kool, en Kroes (1994). Bovendien bevat het Verdrag van Maastricht verschillende veiligheidskleppen om dit te voorkomen. De ECB wordt onafhankelijk en de nationale overheden mogen hun tekort niet financieren via de eigen centrale bank en daarmee het monetaire beleid verstoren. Tenslotte stelt de Grauwe nog voor landen geen stemrecht in de ECB te geven voor ze aan de convergentiecriteria voldoen.

Verschillen in ontwikkeling en structuur zijn wel een serieus probleem. In een breed samengestelde EMU is de kans op asymmetrische schokken groter dan in een EMU waar slechts de koplopers deel van uitmaken, terwijl de mogelijkheden van budgettair stabilisatiebeleid althans in de eerste jaren vrijwel nul zijn. Het perspectief op economische en politieke spanningen is dan volop aanwezig. Een extra kritiekpunt op het voorstel van de Grauwe is dat deelname aan de EMU op basis van vrijwilligheid plaatsvindt. Hierdoor kan een complex strategisch spel ontstaan over wie wel en wie niet wil toetreden, afhankelijk van de andere deelnemers, en blijft ook de moge- 
lijkheid open dat een aantal landen er buiten blijft en er dus binnen de interne markt nog steeds wisselkoersproblemen kunnen ontstaan. Ook het risico van spijtoptanten is levensgroot aanwezig.

\subsection{Evaluatie}

Geen van de twee opties is erg aantrekkelijk. Het toepassen van de criteria leidt tot een - misschien wel semi-permanente - tweedeling yan de EMU met gecompliceerde wisselkoersafsprakerr en vrijwel onvermijdelijke wisselkoersfluctuaties tussen de ins en outs met alle risico's van dien voor de interne markt. In een EMU van 15 landen neemt de kans op asymmetrische schokken toe, wat óók tot instabiliteit kan leiden.

Het probleem in beide varianten is dat de normaal in een economie potentieel aanwezige stabilisatie via monetair en budgettair beleid bewust wordt uitgeschakeld om politici minder discretionaire en verstorende invloed te geven. Dit leidt tot hogere aanpassingskosten bij (asymmetrische) schokken.

Eén optie is om de nu gehanteerde normen voor budgetdiscipline te laten vallen, zodat landen individueel hun financieel overheidsbeleid kunnen gebruiken voor stabilisatie (en herverdeling). Met name bij de sterke landen met een traditioneel goede budget-discipline leidt dit tot vrees voor hogere kosten in de toekomst die op hen afgewenteld gaan worden. Politiek lijkt hiervoor geen draagvlak te zijn. Deze oplossing blinkt daarnaast niet uit in solidariteit; elk land wordt geacht de eigen problemen op te lossen. De kans dat politici in een land dat door een negatieve schok getroffen wordt, de verantwoordelijkheid bij de EMU zullen leggen is niet denkbeeldig. Onwil om hiervoor op Europees niveau te compenseren kan dan snel aanleiding zijn tot onderlinge fricties.

Het alternatief is het (gedeeltelijk) centraliseren van budgettaire bevoegdheden op Europees niveau zodat een automatisch stabilisatie-mechanisme ontstaat, waarbij overdrachten van landen 
met hoge groei naar landen met lage groei plaatsvinden. Hoewel dit vanuit verzekeringstechnisch oogpunt efficiënt is, is ook dit geen haalbare kaart. Het vereist een verdergaande vorm van politieke unie, waarvoor het draagvlak ontbreekt en gaat bovendien voorbij aan allerlei uitvoeringsproblemen zoals de vermenging van stabilisatie- en herverdelingseffecten van zulke overdrachten, het ontstaan van een extra Brusselse bureaucratie en het gevaar van afwenteling tussen landen, zie ook Alesina en Perotti (1995a).

\section{Intermezzo: de parallel met Europese fusies}

Hoe verhelderend een economische analyse van de EMU ook mag zijn, ze kan nooit een volledig beeld geven, omdat Europese integratie meer is dan een kille rekensom. Uiteindelijk zijn kwesties van cultuur en identiteit misschien veel belangrijker voor zo'n proces. Een parallel met grensoverschrijdende fusies tussen bedrijven ligt hierbij voor de hand.

\subsection{Determinanten fusie-succes}

In een recent onderzoek naar fusies tussen Duitse en Nederlandse bedrijven, concludeert Olie (1996) dat grensoverschrijdende fusies in het algemeen schaars zijn, en successen nog schaarser. Hij onderscheidt een zestal factoren die het succes van zulke fusies kunnen bevorderen. Hoewel de EMU nog geen poging tot volledige politieke eenwording (fusie) is en de landen van de EU geen bedrijven zijn, wil ik hetzelfde kader hier gebruiken om inzicht te verschaffen in de kans op succes van de EMU. In tabel 4 staan de zes factoren weergegeven. Per argument is in de derde kolom aangegeven in welke mate het mijns inziens bijdraagt aan het succes van de EMU. De uitkomst is niet erg hoopgevend. 
Tabel 4 Succesfactoren bij grensoverschrijdende fusies

\begin{tabular}{|l|l|l|}
\hline Factoren: & Succes bij: & In EMU: \\
\hline $\begin{array}{l}\text { 1. omgevingsfactoren: } \\
\begin{array}{l}\text { 2. strategische aansluiting } \\
\text { en besluitvorming: }\end{array}\end{array}$ & $\begin{array}{l}\text { - hoge economische groei } \\
\text { - weinig alternatieven }\end{array}$ & $\begin{array}{l}\text { - duurzame fit } \\
\text { - } \text { en integratie }\end{array}$ \\
\hline 3. culturele verschillen: & $\begin{array}{l}\text { - gelijksoortige instituties } \\
\text { - beperking culturele conflicten }\end{array}$ & + \\
\hline 4. organisatie-identiteit: & - zwakke wij/zij tendensen & - \\
\hline 5. organisatievorm na fusie: & - snelle en sterke integratie & - \\
\hline 6. top-management: & - gezamenlijke visie & - \\
\hline
\end{tabular}

\subsection{EMU als fusie: de kans op succes}

Recessies zijn moeilijk ver vooruit te voorspellen, maar de kans er op is ook na 1999 zeker aanwezig. Als de eerste jaren van de EMU toevallig gekenmerkt worden door ongunstige omstandigheden zoals lage economische groei, zijn spanningen vrijwel onvermijdelijk. Een EMU moet dus zo vorm gegeven worden, dat het dergelijke schokken kan weerstaan. Dit is te meer belangrijk omdat er een alternatief aanwezig is - namelijk een eigen munt die zich binnen een bepaalde bandbreedte kan bewegen - dat niet wezenlijk slechter is. De kosten van het uit de EMU stappen zijn tenslotte niet prohibitief. Uit de voorgaande analyse is duidelijk geworden dat er geen overeenstemming bestaat over het uiteindelijke doel en het nut van de eenwording. Het integratieproces zelf is bovendien door onzekerheden en onduidelijkheden omgeven. 
Op het gebied van cultuur, gewoontes en gebruiken, zijn er binnen de Europese Unie enorme verschillen. Van homogeniteit is geen sprake. Nauw verweven hiermee is de mate waarin individuen zich (blijven) identificeren met hun eigen land (organisatie). Dat nationale gevoelens overal sterk leven behoeft nauwelijks betoog. Kortom, door culturele verschillen en nationale identificatie is het conflictpotentieel in ruime mate aanwezig. Voorlopig wordt dit met name beperkt door het principe van subsidiariteit. Wet- en regelgeving en uitvoering ervan vindt plaats op het laagst mogelijke niveau. In feite komt dit neer op een bewuste beperking van de integratie. Op korte termijn neemt dit spanningen weg, op lange termijn echter vertraagt het het fusieproces en vermindert het de kansen op succes. Immers, de als vijfde genoemde factor stelt dat een fusie succesvoller is naarmate er meer nieuwe identificatiesymbolen en gezamenlijke doelen ontwikkeld worden, de onderlinge afhankelijkheid benadrukt wordt, en er uitwisseling en rotatie van personen plaatsvindt, dus wanneer de Europese staatsburger op het toneel verschijnt, zie ook Goodhart (1995).

De rol van het top-management tenslotte is cruciaal. Continuïteit, gedeelde visie, en het vermogen die visie ook op de achterban over te brengen dragen bij aan het succes van de EMU. Ook hier scoort Europa laag. Met name de halfjaarlijkse bijeenkomsten van Europese regeringsleiders - het meest zichtbare symbool van Europese samenwerking - dragen bij aan het beeld van een Europa waarin elk land zoveel mogelijk op het behalen van korte-termijn eigenbelang uit is. Wisselingen van de wacht - denk aan Chirac voor Mitterand - kunnen een forse koerswijziging betekenen, van een gedeelde visie is niet echt sprake, en alle enquêtes wijzen uit dat het met het overdragen van die visie op de bevolking slecht gesteld is. 


\section{EMU: wanneer?}

$\mathrm{Nu}$ het momentum van het Verdrag van Maastricht verdwenen is, lijkt het alleen van belang of landen hijgend de eindstreep kunnen halen en zich daarmee kwalificeren voor de EMU. Het zou echter een misverstand zijn te denken dat er na 1 januari 1999 tijd is om bij te komen van de gepleegde inspanningen. Integendeel, de echte test komt pas in de eerste jaren van de EMU, als de directe voordelen van de eenwording niet of nauwelijks zichtbaar zijn, maar negatieve schokken zich wel aandienen.

De voortekenen zijn wat dat betreft niet gunstig. Het Europese eenwordingsproces zoals verwoord in het Verdrag van Maastricht heeft de karakteristieken van een kil verstandshuwelijk. Bij gebrek aan onderling vertrouwen en solidariteit moeten huwelijkse voorwaarden, d.w.z. regels en harde afspraken, het werk doen, zie CPB (1996). Die afspraken restricteren het monetaire en budgettaire beleid vrijwel volledig en laten in ieder geval voorlopig geen ruimte voor de automatische demping van eventuele asymmetrische schokken. Omdat er ook geen sprake is van een stabilisatiemechanisme op Europees niveau, moeten zulke schokken opgevangen worden op met name de arbeidsmarkt. De tolerantie hiervoor zal niet groot zijn na de reeds verrichte inspanningen voorafgaand aan de EMU. Gevoegd bij de in veel landen bestaande twijfels omtrent de voordelen van de EMU, en de geringe mate van identificatie met Europa als organisatorische eenheid, ligt het voor de hand dat de EMU snel als zondebok zal worden gebruikt. Het is bovendien niet te verwachten dat de Europese regeringsleiders in crisissituaties meer als eenheid zullen optreden dan voorheen, zodat krachtig Europees leiderschap een illusie blijft.

Komt er na de totstandkoming van de EMU een zodanige crisis dat de EMU uiteenvalt, dan is de schade groot. Anderzijds zou een tijdig en unaniem besluit van de Europese regeringsleiders om het tijdpad voor de EMU met enkele jaren vooruit te schuiven, niet hoe- 
ven te leiden tot heftige reacties op financiële markten, mits de individuele landen een verstandig macro-economisch beleid blijven voeren.

In zo'n scenario kan meer ervaring worden opgedaan met het huidige stelsel van wisselkoersafspraken. Wellicht blijkt dat de 15 procent fluctuatiemarges ook op langere termijn geen bedreiging vormen voor de interne markt. In dat geval is zelfs afstel een optie. Daarnaast ontstaat tijd en ruimte om te bezien of overeenstemming mogelijk is over vorm en inhoud van een politieke unie. Belangrijke elementen daarbij zijn onderling vertrouwen en solidariteit. Als dit niet lukt, komt opnieuw de mogelijkheid van afstel in beeld.

Mijn conclusie kan simpel worden samengevat met behulp van een belangrijke les uit de moderne financieringstheorie: de keuze voor een investeringsproject met een hoog verwacht rendement impliceert normaal gesproken een corresponderend hoge risicograad. Anderzijds is het zeer wel mogelijk - maar niet erg verstandig - een investeringsproject te kiezen met een laag verwacht rendement en toch een hoog risico. Ik concludeer dat de EMU althans op dit moment tot die laatste categorie behoort. 


\section{Dankwoord}

Ter afsluiting van mijn inaugurele rede wil ik graag van de gelegenheid gebruik maken om iedereen die binnen en buiten deze faculteit aan mijn benoeming als hoogleraar Geld-, Krediet-, en Bankwezen en Europese Financiële Markten heeft meegewerkt te bedanken voor het in mij gestelde vertrouwen.

De monetaire economie is - zoals hopelijk uit mijn rede blijkt -, een dynamisch vakgebied met hoge maatschappelijke relevantie. Studenten zijn daar gelukkig al van overtuigd, gezien de groeiende belangstelling van studenten voor de specialisatie 'Money and Banking'. Ik beschouw het als een uitdaging om via onderwijs en onderzoek aan de ontwikkelingen op dit terrein te kunnen blijven bijdragen. Dat dat kan binnen de jongste en ongetwijfeld meest dynamische economische faculteit van Nederland doet me deugd.

Omdat iedereen onderhand wel aan een verfrissing toe zal zijn, wil ik niet zo ver gaan om iedereen die aan de prettige en productieve werkomgeving hier bijdraagt - staf, ondersteunend personeel, en studenten -, met name te noemen. Wel is in dit verband een speciaal dankwoord voor vier personen op zijn plaats.

Joan Muysken heeft mij ruim vijf jaar geleden naar de vakgroep Algemene Economie in Maastricht gehaald en mij vanaf het begin het vertrouwen en de vrijheid gegeven om mijn eigen weg binnen de faculteit te vinden. Van zijn bestuurlijke inzicht en ervaring heb ik bovendien veel geleerd. Ik hoop er in de nabije toekomst goed gebruik van te kunnen maken.

Tom van Veen is vanaf het begin een onmisbare en onuitputtelijke vraagbaak geweest voor alle onderwijskundige en organisatorische aspecten van deze organisatie en heeft me de noodzakelijke beginselen van het probleem-gestuurd onderwijs bijgebracht. In het onderwijs zijn we een steeds hechter en beter functionerend team geworden. Hopelijk kunnen we het komend jaar de samenwerking uitbreiden richting monetair onderzoek. 
Achter de schermen zorgt Lilian Raetsen al jaren efficiënt en loyaal voor een goede sfeer en voor de nodige ondersteuning van onderwijs en onderzoek. Haar aandeel mag zeker niet onderschat worden.

De plezierige samenwerking op het gebied van onderwijs en onderzoek met Kees Koedijk gaat ver terug in de tijd, maar blijft ook hier vruchten dragen in de vernieuwde vorm van het Limburgs Instituut voor Financiële Economie, LIFE.

Een mens leeft niet van brood (of werk) alleen en vakidioten zijn er al genoeg. Lieve Marijke, bedankt voor alles, niet in het minst voor je bereidheid naar Maastricht te verhuizen. Vandaag wil ik je echter speciaal bedanken voor het openhouden van een wijdere horizon dan de monetaire economie. Lieve Marrit, Arjen, en Anniek, niet alleen geniet ik elke dag van jullie, ik leer ook steeds bij. Mocht ik vandaag iets te kritisch geweest zijn, dan is dat mede doordat jullie me steeds weer helpen herinneren aan de betekenis en het belang van het woord 'waarom'.

Ik heb gezegd. 


\section{Literatuur}

Alesina, A. en R. Perotti (1995a), 'Economic Risk and Political Risk in Fiscal Unions', NBER working paper no. 4992, januari

Alesina, A. en R. Perotti (1995b), 'Fiscal Expansions and Fiscal Adjustments in OECD Countries', NBER working paper no. 5214, augustus

Bean, C.R. (1992), 'Economic and Monetary Union in Europe', The Journal of Economic Perspectives, vol. 4, no.4, 1992, pp. 3152

Boesschoten, W.C. en A.C.J. Stokman (1996), 'De Invoering van de Euro: Uitkomsten van een Enquête voor Nederland', Kwartaalbericht De Nederlandsche Bank, maart, pp. 73-92

Brakman, S. en J.H. Garretsen (1996), 'Zijn de Economische en de Monetaire Unie Strijdig?', Economisch Statistische Berichten, 7 februari, pp. 112-116

Buiter, W., G. Corsetti en N. Roubini (1993), 'Maastricht's Fiscal Rules', Economic Policy, april, pp. 57-100

Centraal Planbureau (1996), 'Centraal Economisch Plan 1996', Den Haag

Conway, P. (1995), 'Currency Proliferation: The Monetary Legacy of the Soviet Union', Essays in International Finance, no. 197, juni

Delors, J. (1996), 'The Economic and Monetary Union in the Framework of a United Europe', SUERF Lezing, Maastricht

De Nederlandsche Bank (1996), 'Jaarverslag 1995', Amsterdam

Eichengreen, B. (1993), 'European Monetary Unification', Journal of Economic Literature, vol 31, september, pp. 1321-1357

Eichengreen, B. (1996), 'A More Perfect Union? The Logic of Economic Integration', Essays in International Finance, no. 198, juni

Eichengreen, B., en C. Wyplosz (1993), 'The Unstable EMS', Brookings Papers on Economic Activity, 1, pp. 51-143 
Feldstein, M. (1992), 'The Case Against EMU', The Economist, 13 juni, pp. 19-22

Frankel, J.A. en S.-J. Wei (1993), 'Trade Blocs and Currency Blocs', NBER working paper no. 4335

Fratianni, M. en J. Von Hagen (1992), 'The European Monetary System and European Monetary Union', Westview Press

Goodhart, C. (1995), 'The Political Economy of Monetary Union', in P. Kenen (ed.), Understanding Interdependence: The Macroeconomics of the Open Economy, ch. 8

Goodhart, C. (1996), 'European Monetary Integration', European Economic Review, vol. 40, no. 3-5, pp. 1083-1090

Grauwe, P. de (1987), 'International Trade and Economic Growth in the EMS', European Economic Review, vol. 31, pp. 389-398.

Grauwe, P. de (1994a), 'The Economics of Monetary Integration', 2nd. ed., Oxford University Press

Grauwe, P. de (1994b), 'Towards EMU without the EMS', Economic Policy, pp. 149-185

Grauwe, P. de (1996), 'Monetary Union and Convergence Economics', European Economic Review, april, vol. 40, no. 3-5, pp. 1091-1102

Gros, D. en N. Thygesen (1992), 'European Monetary Integration: From the European Monetary System to European Monetary Union', Longman

Keuzenkamp, H. (1996), 'Monetaire Aspirine', Economisch Statistische Berichten, 19 juni, p. 545

Kindleberger, C.P. (1993), 'A Financial History of Western Europe', 2nd. ed., Oxford University Press

Koedijk, K.G., C.J.M. Kool en T.R.P.J. Kroes (1994), 'Changes in World Real Interest Rates and Inflationary Expectations', Weltwirtschaftliches Archiv, vol. 130, no. 4, pp. 712-729.

Olie, R.L. (1996), 'European Transnational Mergers', Maastricht 
Orphanides, A., en D.W. Wilcox (1996), 'The Opportunistic Approach to Disinflation', Finance and Economics Discussion Series $96-24$, mei

Taylor, C. (1995), 'EMU 2000? Prospects for European Monetary Union', Chatham House Papers, The Royal Institute of International Affairs

Vinãls, J. (1996), 'European Monetary Integration: A Narrow or a Wide EMU?', European Economic Review, vol. 40, no. 3-5, pp. 1103-1110

Wellink, A.H.E.M. (1996), 'Maastricht en Omgeving: Overheidsfi, nanciën op Langere Termijn', Kwartaalbericht De Nederlandsche Bank, maart, pp. 59-64

Wellink, A.H.E.M., en K.H.W. Knot (1996), 'Geloofwaardigheid, Beleidsvrijheid en de Euro', Economisch Statistische Berichten, 29 mei, pp. 484-489 